\title{
PERANAN BAITUL MAAL WAT TAMWIL DALAM MENINGKATKAN USAHA MIKRO MELALUI PEMBIAYAAN MUDHARABAH (Studi Kasus BMT Fajar Cabang Cileungsi Bogor Periode 2018-2019)
}

\author{
Sarwo Edy ${ }^{1}$, Rayuningsih ${ }^{2}$ \\ ${ }^{1}$ Universitas Pelita Bangsa, doctor.sarwo25@gmail.com \\ 2 Universitas Pelita Bangsa, rayuningsih62@gmail.com
}

\section{A R T I C L E I N F O}

Article history:

Received : $17 / 03 / 2021$

Revised : 17/03/2021

Accepted: 02/04/2021

Key words:

Islamic Microfinance Institutions;

UMKM entrepreneurs; mudharabah financing

DOI:

Doi.org/10.37366/jespb.v6i01.176

\section{A B S T R A C T}

This research is motivated by the presence of Islamic Microfinance Institutions in the form of BMT, namely BMT Fajar in the community, especially the people of Cileungsi-Bogor, is expected to bring changes in various aspects of people's lives. In the case of the people of Cileungsi Village, Bogor Regency, where the community is not familiar with Sharia Microfinance Institutions such as BMTs well. Until finally people prefer to make loans to Mobile Banks or so-called loan sharks with interest that are not small as business financing capital, it is the habit of borrowing capital to loan sharks that is the problem and attracts the author's interest to do research.

This study aims to determine the background of BMT Fajar in providing mudharabah financing, to know the mudharabah financing procedure, and to determine the role of mudharabah financing in BMT Fajar. The methodology used in this study used a qualitative approach, namely field research and library research. Field research is data collection techniques using observation, interview and documentation methods with Branch Heads, BMT Fajar Cileungsi-Bogor UMKM entrepreneurs, and their business customers. So as to get accurate data on the research process, and library research data, namely by means of data analysis using inductive, deductive and comparative.

Through interviews and observations, it can be seen that based on the results of the research it can be concluded that the role of BMT Fajar's Cileungsi branch in improving micro-businesses is by BMT Fajar to provide financing products that are not difficult in terms of capital, which do not apply the usury system in the operational system, but are replaced with a profit sharing system. between BMT and members in accordance with Islamic Sharia. One of them is through Mudharabah financing. Because they saw many Little Pengusa who had gone out of business. Whereas Small and Medium Enterprises have the potential for development in facing the Economic Crisis.

\section{A B S T R A K}

Penelitian ini dilatarbelakangi dengan hadirnya Lembaga Keuangan Mikro Syariah dalam wujud BMT yaitu BMT Fajar ditengah masyarakat khususnya masyarakat Cileungsi Bogor, diharapkan membawa perubahan dalam berbagai sisi kehidupan masyarakat. Dalam kasus masyarakat Desa Cileungsi Kabupaten Bogor, dimana masyarakat kurang mengenal Lembaga Keuangan Mikro Syariah seperti BMT dengan baik. Hingga akhirnya masyarakat lebih memilih melakukan pinjaman kepada Bank Keliling atau biasa disebut dengan Rentenir dengan bunga yang tidak sedikit sebagai modal pembiayaan usaha, Kebiasaan peminjaman modal kepada rentenirlah yang menjadi permasalahan dan menarik minat penulis untuk melakukan penelitian.

Penelitian ini bertujuan untuk mengetahui Latar belakang BMT Fajar dalam Memberikan Pembiayaan Mudhorobah, Mengetahui Prosedur Pembiayaan 
Mudhorobah, dan Untuk Mengetahui Peranan Pembiayaan Mudhorobah di BMT Fajar. Metodologi yang digunakan dalam penelitian ini menggunakan Pendekatan Kualitatif yaitu Penelitian Lapangan dan penelitian kepustakaan. Penelitian lapangan yaitu teknik pengumpulan data dengan Metode Observasi, Wawancara dan Dokumentasi dengan Kepala Cabang, Pelaku Usaha Mikro BMT Fajar Cileungsi Bogor, dan Pelanggan Usahanya. Sehingga mendapat data yang akurat pada proses penelitian, dan Data Penelitian Kepustakaan, yaitu dengan Alat Analisis Data menggunakan Induktif, Deduktif dan Komparatif.

Melalui Wawancara dan Observasi dapat diketahui berdasarkan hasil penelitian dapat disimpulkan bahwa Peranan BMT Fajar Cabang Cileungsi dalam Meningkatkan Usaha Mikro adalah dengan BMT Fajar Mengadakan Produk Pembiayaan yang Tidak Sulit dalam Syarat Permodalannya, yang Tidak Menerapkan Sistem Riba dalam Sistem Operasional, namun diganti dengan Sistem Bagi Hasil antara BMT dengan Anggota sesuai dengan Syariat Islam. Salah satunya dengan Pembiyaan Mudhorobah, Karena melihat banyak Pengusa Kecil yang mengalami gulung tikar. Padahal Usaha Kecil Menengah mempunyai Potensi untuk Perkembangan dalam Menghadapi Krisis Ekonomi.

\section{PENDAHULUAN}

Ekonomi merupakan salah satu hal yang tidak bisa dipisahkan dari kehidupan manusia. Perkembangan ekonomi suatu negara mendapat pengaruh besar dengan hadirnya beberapa Lembaga Keuangan. Perkembangan usaha mikro, kecil dan menengah (UMKM) di indonesia yang semakin meningkat setiap tahunnya memberikan angin segar bagi Sektor Perekonomian. Menurut Badan Pusat Statistik (BPS) jumlah Usaha Mikro Kecil dan Menengah (UMKM) mencapai 64 juta. Angka tersebut mencapai 99,9 persen dari Keseluruhan Usaha yang Beroperasi di Indonesia. Menurut data Kementerian Koperasi, Usaha Kecil, dan Menengah (KUKM) tahun 2018, jumlah Pelaku UMKM sebanyak 64,2 juta atau 99,99\% dari jumlah Pelaku Usaha di Indonesia. Daya Serap Tenaga Kerja UMKM adalah sebanyak 117 juta pekerja atau 97\% dari Daya Serap Tenaga Kerja Dunia Usaha. Sementara itu Kontribusi UMKM terhadap Perekonomian Nasional (PDB) sebesar 61,1\%, dan sisanya yaitu $38,9 \%$ disumbangkan oleh pelaku usaha besar yang jumlahnya hanya sebesar 5.550 atau 0,01\% dari jumlah Pelaku Usaha. UMKM tersebut didominasi oleh Pelaku Usaha Mikro yang berjumlah 98,68\% dengan Daya Serap Tenaga Kerja sekitar $89 \%$. Sementara itu sumbangan Usaha Mikro terhadap PDB hanya sekitar 37,8\%.
Usaha mikro yang sangat banyak dan daya serap tenaga kerja sangat besar. Pemerintah menyadari akan potensi UMKM tersebut, oleh sebab itu, beberapa tahun terakhir ini, Pemerintah mengambil kebijakan untuk meningkatkan Kapasitas Usaha Mikro dan Kecil agar dapat naik kelas menjadi Usaha Menengah. Program Pemulihan Ekonomi untuk UMKM salah satu sasaran program PEN adalah menggerakkan UMKM. Untuk itu, Pemerintah mengambil beberapa kebijakan antara lain Subsidi Bunga Pinjaman, Restrukturisasi Kredit, pemberian jaminan Modal Kerja dan Insentif Perpajakan. Adapun dana yang dialokasikan untuk skema tersebut adalah sebesar Rp123,46 triliun (KEMENKEU, 2020).

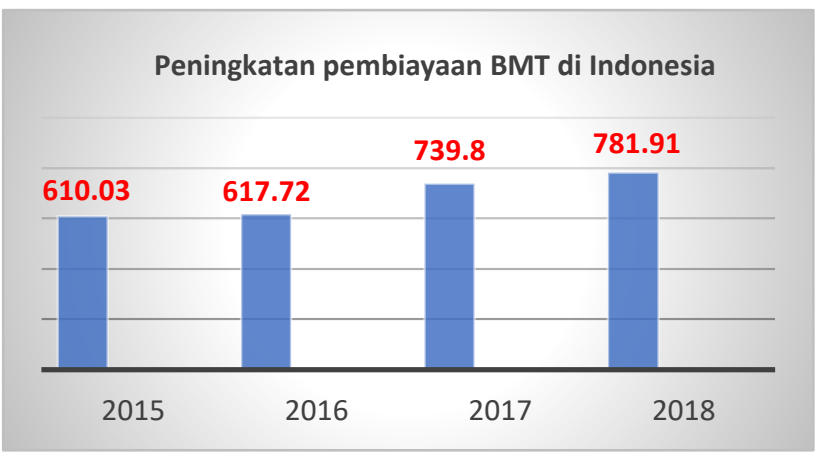

Gambar 1. Peningkatan Pembiayaan BMT

Pertumbuhan Baitul Maal wat Tamwil (BMT) sejak pertama kali diperkenalkan pada awal 2000-an 
hingga saat ini terus mengalami peningkatan dan mencapai titik yang luar biasa. Selama ini pengawasan dan pembinaan Lembaga Keuangan Mikro Syariah termasuk Koperasi BMT berada pada dua kelembagaan yaitu Otoritas Jasa Keuangan (OJK) dan Kementerian Koperasi dan UMKM. Sebagian besar BMT memilih untuk Berbadan Hukum Koperasi. Sedangkan hanya beberapa saja yang memilih untuk di bawah OJK. Pertumbuhan BMT cukup Signifikan, di mana berdasarkan data Permodalam BMT (PBMT) Ventura sebagai Asosiasi BMT di Indonesia, terdapat sekitar 4.500 BMT di 2015 yang melayani kurang lebih 3,7 juta orang dengan aset sekitar Rp16 triliun yang dikelola sekitar 20 ribu orang. Berdasarkan data dari Kementerian Koperasi dan UKM menunjukkan jumlah unit usaha koperasi di Indonesia mencapai 150.223 unit usaha, di mana terdapat 1,5 persen koperasi yang berbadan hukum. Keberadaan BMT diharapkan mampu mendorong sektor usaha mikro dan kecil. Hal tersebut dianggap penting karena menjadi Penggerak Perekonomian Indonesia. Jumlah penduduk Indonesia yang menjadi pengusaha sektor UMKM terus mengalami peningkatan setiap tahunnya. Pembiayaan yang disalurkan pun demikian. di 2015 sebanyak Rp 610,03 triliun, 2016 sebanyak Rp 671,72 triliun, 2017 sebanyak Rp 739,80 triliun, dan 2018 sebanyak Rp 781,91 triliun. Jika untuk skala usaha menengah dapat mengakses kredit melalui bank, sedangkan untuk Usaha Mikro dan Kecil dapat memanfaatkan keberadaan Koperasi atau BMT (medcom.id, 2018).

Baitul Maal wat Tamwil (BMT) atau disebut juga dengan "Koperasi Syariah", BMT terdiri dari dua istilah, yaitu "baitul maal" dan "baitu tamwil". Baitul maal merupakan istilah untuk Organisasi yang berperan dalam mengumpulkan dan menyalurkan dana non-profit, seperti zakat, infak dan sedekah. Baitu tamwil merupakan istilah untuk Organisasi yang mengumpulkan dan menyalurkan dana komersial. dengan demikian BMT mempunyai peran ganda yaitu fungsi sosial dan fungsi komersial. Dalam Baitul Maal wat Tamwil (BMT) sendiri memiliki beberapa produk yang ditawarkan diantaranya simpanan serta pembiayaan. Contohnya pada BMT Fajar Cileungsi Bogor memiliki beberapa produk simpanan dan pembiayaan. Mudharabah adalah akad kerjasama bisnis anatara dua pihak, yaitu pihak yang mengelola usaha/pemilik bisnis yang disebut sebagai Mudharib dan pihak yang memiliki modal yang disebut sebagai Shahibul Maal. Dalam akad tersebut poin pentingnya adalah terletak di awal yaitu kesepakatan atas nisbah bagi hasil (qazwat,2018). Pembiayaan Mudharabah adalah bentuk bentuk kerjasama anatara BMT Fajar dengan Anggota, dimana BMT Fajar sebagai Pemodal dan Anggota sebagai Pengelola Usaha. Keuntungan usaha tersebut akan dibagi sesuai kesepakatan diawal Prosentase keuntungan disebut Nisbah (bmtfajar,2015).

Kepercayaan Masyarakat terhadap BMT Fajar yang berada di Komplek Ruko Permata Cibubur, Jalan Cileungsi jonggol Blok H6 No. 46, Cileungsi kidul, Kecamatan Cileungsi, Bogor, Jawa Barat 16820, menuntut pihak BMT untuk profesional dalam pelaksanaan opersional dan mensosialisasikan produk-produknya. BMT yang dalam pelaksanaanya disalurkan dalam beberapa produk usaha, salah satunya dengan Pembiayaan Muhorobah (Iswanto,2012). Masyarakat Cileungsi banyak yang membutuhkan modal usaha namun tidak mampu menjangkau pelayanan yang diberikan oleh pemerintah melalui Perbankan khususnya Bank Konvensional dikarenakan adanya persyaratan yang memberatkan, yaitu bunga bank yang tinggi, sehingga dalam memenuhi kebutuhan usahanya para nasabah maupun para pelaku usaha sangat berharap dengan adanya BMT.

\section{Rumusan Masalah}

Berdasarkan uraian pada latar belakang yang telah dijabarkan di atas, maka penulis merumuskan masalah sebagai berikut:

1) Bagaimana Latar Belakang BMT Fajar dalam Meberikan Pembiayaan Mudhorobah?

2) Bagaimana Prosedur Pembiayaan Mudhorobah di BMT Fajar?

3) Bgaimana Peranan Pembiayaan Mudhorobah di BMT Fajar terhadap Perkembangan Usaha Kecil Menengah (UKM) di Kecamatan Cileungsi Bogor tahun 2019? 


\section{Tujuan Penelitian}

Berdasarkan rumusan masalah di atas, maka penelitian ini bertujuan sebagai berikut:

1) Untuk Mengetahui Latar Belakang BMT Fajar dalam Mengadakan Pembiayaan Mudharabah.

2) Untuk Mengetahui Prosedur Permohonan Pembiayaan Mudharabah yang dilaksanakan di BMT Fajar.

3) Untuk mengetahui peranan pembiayaan Mudharabah di BMT Fajar terhadap Tingkat Perkembangan Usaha Kecil Menengah (UKM) di Kecamatan Cileungsi Bogor.

\section{TINJAUAN TEOIRITIS}

\section{BMT}

BMT adalah kependekan dari kata Balai Usaha Mandiri Terpadu atau Baitul Maal Wat Tamwil yaitu Lembaga Keuangan Mikro yang berlandaskan dengan Prinsip-prinsip Syari'ah, terbagi menjadi dua yaitu Baitul maal yang adalah rumah dana dan Baitul tamwil adalah rumah usaha. Baitul maal berfungsi untuk mengumpulkan dan mentasyarufkan dana sosial sedangkan baitul tamwil berfungsi untuk lembaga bisnis. Baitul maal lebih mengarah ke usaha yang non profit yang mengumpulkan dana-dana dari infaq, zakat, wakaf dan sadaqah yang kemudian disalurkan kepada yang berhak menerimanya. Sedangkan Baitul Tamwil mengarah pada pengumpulan dan penyaluran dana yang kegiatannya mengembangkan usaha produktif yang meningkatkan kualitas usaha ekonomi pengusaha kecil dan menengah, antara lain dengan cara mendorong kegiatan menabung dan pembiayaan usaha ekonomi (Al-kaaf, 2002).

Menurut Antonio (2001) Pembiayaan merupakan salah satu tugas BMT, yaitu pemberian fasilitas penyediaan dana untuk memenuhi kebutuhan pihak-pihak yang merupakan defisit unit. Menurut sifat penggunaanya, pembiayaan dapat dibagi menjadi dua hal yaitu:

a) Pembiayaan Produktif, yaitu pembiayaan yang ditunjukkan untuk memenuhi kebutuhan produksi dalam arti luas, yaitu untuk peningkatan usaha, baik usaha produksi, perdagangan maupun investasi.

b) Pembiayaan konsumtif, yaitu pembiayaan yang digunakan untuk memenuhi kebutuhan konsumsi, yang akan habis digunakan untuk pemenuhan kebutuhan.

\section{Mudharabah}

Menurut pendapat ahli fiqih mudharabah yaitu suatu perjanjian dimana seorang memberikan hartanya kepada orang lain berdasarkan prinsip dagang dimana keuntungan yang diperoleh akan dibagi berdasarkan pembagian yang disetujui oleh para pihak, misalnya setengah atau seperempat dari keuntungan. Secara teknis, mudharabah adalah akad kerja sama antara dua pihak dimana pihak pertama shahibul mal menyediakan seluruh modal, sedangkan pihak lainnya menjadi pengelola. Keuntungan usaha secara mudharabah dibagi menurut kesepakatan yang dituangkan dalam kontrak, sedangkan apabila rugi ditanggung oleh pemilik modal selama kerugian itu bukan akibat kelalaian si pengelola. Seandainya kerugian itu diakibatkan karena kecurangan atau kelalaian si pengelola harus bertanggung jawab atas kerugian tersebut (Antonio,2001).

Adapun Fatwa DSN tentang pembiayaan mudharabah adalah sebagai berikut (Sholihin,2010):

a) Pembiayaan Mudharabah adalah pembiayaan yang disalurkan oleh LKS kepada pihak lain untuk suatu usaha yang produktif.

b) Dalam pembiayaan ini LKS sebagai shahibul maal (pemilik dana) membiayai $100 \%$ kebutuhan suatu proyek (usaha), sedangkan pengusaha (nasabah) bertindak sebagai mudharib atau pengelola usaha.Jangka waktu usaha, tata cara pengembalian dana, dan pembagian keuntungan ditentukan berdasarkan kesepakatan kedua belah pihak (LKS dengan pengusaha).

c) Mudharib boleh melakukan berbagai macam usaha yang telah disepakati bersama dan sesuai dengan syariah dan LKS tidak ikut serta dalam managemen perusahaan atau proyek tetapi 
mempunyai hak untuk melakukan pembinaan dan pengawasan.

d) Jumlah dana pembiayaan harus dinyatakan dengan jelas dalam bentuk tunai dan bukan piutang.

e) LKS sebagai penyedia dana menanggung semua kerugian akibat dari mudharabah kecuali jika mudharib (nasabah) melakukan kesalahan yang disengaja, lalai, atau menyalahi perjanjian.

f) Pada prinsipnya dalam pembiayaan mudharabah tidak ada jaminan, namun agar mudharib tidak melakukan penyimpangan, LKS dapat meminta jaminan dari mudharib atau pihak ketiga. Jaminan ini hanya dapat dicairkan apabila mudharib terbukti melakukan pelanggaran terhadap hal-hal yang telah disepakati bersama dalam akad.

g) Kriteria pengusaha, prosedur pembiayaan, dan mekanisme pembagian keuntungan diatur oleh LKS dengan memperhatikan fatwa DSN.

h) Biaya operasional dibebankan kepada mudharib.

\section{Kerangka Pikir}

Untuk menggambarkan penjabaran dari latar belakang penelitian ini dapat dituangkan dalam kerangka pemikiran sebagai berikut:

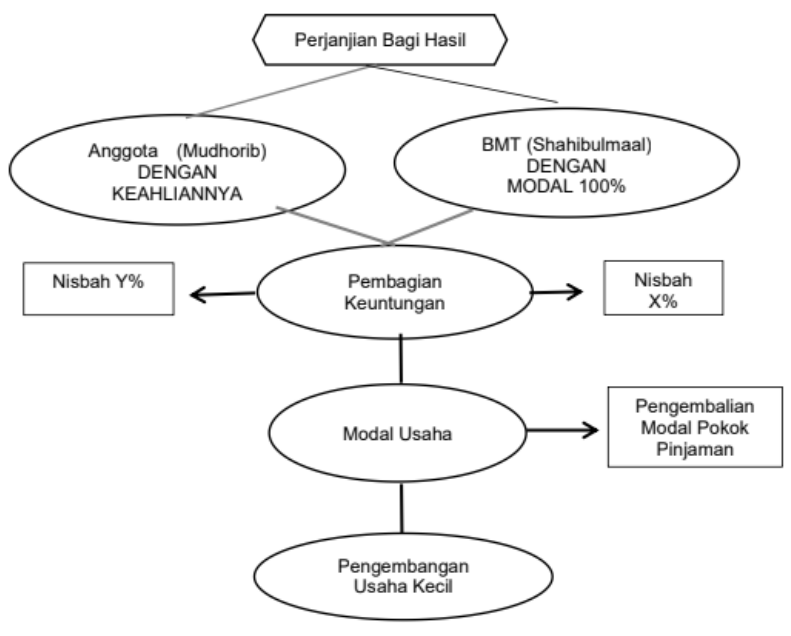

Gambar 2. Kerangka Pikir

\section{METODE PENELITIAN}

Pendekatan yang digunakan pada penelitian ini adalah kualitatif deskriptif. Penelitian ini dilakukan di BMT Fajar Cabang Cileungsi, yang terletak di Komplek Ruko Permata Cibubur, Jalan Cileungsijonggol Blok H6 No. 46, Cileungsi kidul, Kec.Cileungsi, Bogor, Jawa Barat 16820 dengan jenis peneliti pustaka dan lapangan. Teknik pengumpulan data menggunakan teknik observasi, wawancara, dan dokumentasi.

\section{HASIL DAN PEMBAHASAN}

\section{Latar Belakang BMT Fajar Cabang Cileungsi Bogor Dalam Memberikan Produk Pembiayaan Mudharabah}

Menurut undang undang no 7 tahun 1992 tentag perbankan sebagai mana telah diubah dangan undang undang no 10 tahun 1998, bahwa bank adalah badan usaha yang menghimpun dana dari masyarakat dalam bentuk simpanan dan menyalurkan kepada masyarkat dalam bentuk pembiayaan atau bentuk bentuk lainnya dalam rangka meningkatkan taraf hidup orang banyak. Sedangkan Baitul Maal Wa Tamwil (BMT adalah suatu lembaga yang didalamnya mencakup dua jenis kegiatan yaitu yang pertama, baitul maal yaitu kegiatan menerima dan menyalurkan dana zakat, infaq, sodaqoh. Kedua, baitul Tamwil yaitu lembaga yang kegiatannya mengembangkan usaha usaha produktif dan investasi.

Pihak BMT Fajar lebih mengutamakan pembiayaan bagi usaha kecil, dikarenakan sesuai dengan visi dan misi BMT Fajar yaitu sebagai badan keuangan mikro syariah membantu dan mendorong kemaslahatan usaha kecil menengah dan meberikan pembiayaan sesuai prinsip prinsip syariah yang bebas dari riba, dan melihat masyarakat yang memiliki modal terbatas tetapi berpotensi untuk berkembang maju, apabila usaha kecil mengalami gulung tikar maka akan semakin menambah jumlah angka penggaguran dan kemiskinan di masyarakat cileungsi khususnya dan rakyat Indonesia pada umumnya. Oleh karena itu, dangan pembiayaan mudhorobah dari BMT Fajar, diharapkan dapat membantu permodalan bagi usaha kecil menengah serta dalam pembagunan ekonomi bangsa 
Indonesia, sehingga terwujud kesejahteraan masyarkat Indonesia.

\section{Prosedur Pelaksanaan Pemberian Pembiayaan Mudhorobah kepada BMT Fajar Cileungsi Bogor}

Prosedur pemberian pembiayaan disesuaikan antara permohonan pembiayaan yang diinginkan dengan usaha yang akan dilaksanakan oleh calon anggota, dengan demikian pihak BMT, akan memberikan keterangan lebih lanjut dan akan mengerahkan pembiayaan sesuai dengan usaha yang akan dijalani oleh calon anggota. Adapun prosedur pembiayaan adalah :

\section{a) Sosialisasi}

Penjelasan oleh pihak BMT kepada anggota mengenai tata cara pengajuan pembiayaan dan persyaratan yang harus dipenuhi oleh anggota apabila harus mengajukan pembiayaan kepada BMT.

\section{b) Analisis}

Analisis yang dilakukan olehpihak BMT umtuk menentukan kesanggupan anggota dalam mengembalikan sesuai dengan persyaratan yang terdapat dalam perjanjian pembiayaaan yang sudah disepakati bersama sebelumnya.

c) Jaminan

Dalam hal ini digunakan sebagai agunan anggota kepada BMT, jika anggota sebagai pelaku usaha melakukan kecurangan dan pada akhirnya mengalami kerugian maka pihak BMT mempunyai hak untuk mengambil jaminan tersebut untuk menjadi milik BMT. Hal ini sudah sangat jelas sesuai dengan ketentuan dalam akad mudhorobah, jaminan bisa disertakan dalam perjanjian akad dalam upaya mendapatkan pembiayaan mudhorobah, sebagai alat meminimalisasi resiko yang akan dialami oleh BMT.

\section{d) Persetujuan pembiayaan}

Persetujuan pembiayaan adalah persetujuan atas permohonan anggota yang dilakukan oleh pihak BMT. e) Perjanjian atau akad

Kedua belah pihak BMT Fajar dan anggota saling membuat kesepakatan akan perihal pembiayaan tersebut. Aspek-aspek yang mendukung dari perjanjian tersebut adalah ajangka waktu pengembalian angsuran, nisbah bagi hasil antara anggota sebagai pelaku usaha dengan BMT sebagai pemberi modal, jaminan yang diberikan kepada pihak BMT, legalitas anggota, dan prospek usaha anggota di masa depan.

\section{f) Pencairan pembiayaan}

Setelah meneliti kelengkapan syarat dari anggota, melakukan survey ketempat tinggal, tempat usaha dan jaminan milik anggota, mengadakan rapat dengan komite pembiayaan dan mendapat persetujuan dari komite, maka pihak BMT akan mencairkanyang dibutuhkan oleh anggota sesuai dengan kesepakatan bersama.

g) Perhitungan bagi hasil

Perhitungan bagi hasil adalah perhitungan penerimaan dari nasabah (pelaku usaha) dengan pihak BMT pemberi dana sesui dengan nisbah yang telah disepakati bersama

\section{h) Pembayaran angsuran}

Pembayaran angsuran pembiayaan yang harus diberikan oleh anggota kepada pihak BMT sesuai dengan jangka waktu yang telah disepakati bersama

\section{i) Monitoring}

Pihak BMT akan memantau jalan usaha yang dilakukan oleh calon anggota, apabila anggota (calon anggota) mengalami kesulitan dalam menjalankan usahany, maka pihak BMT akan membantu memberikan solusi dan saran dalam upaya mengatasi kendala yang dihadapi anggota sehingga dapat memperbaiki usaha anggota di masa depan. Lancarnya usaha yang dilakukan naggota akan mempengaruhi kedisiplinan anggota dalam membayar angsuran pembiayaan kepada BMT.

\section{Peran Pembiayaan Mudharabah di BMT Fajar terhadap Usaha Kecil Menengah}

Keberadaan BMT Fajar dirasakan sangat membantu para pengusaha kecil menengah terutama di Kecamatan Cileungsi. Masyarakat 
merasakan bahwa BMT Fajar sangan berperan bagi kelancaran usaha mereka dalam meningkatkan permodalan, hal ini dikarenakan prosedur pembiayaan yang mudah dan tidak berbelit belit serta pencairan dana yang cepat, sehingga mereka dapat segera memutarkan modal pembiayaan dari BMT untuk usaha mereka. Dalam pembiayaan mudhorabah tidak mengenal adanya bunga pinjaman, karena hal itu merupakan riba yang dilarang dalam agama Islam, tetapi dalam pembiayaan mudharabah dikenal adanya sistem bagi hasil yaitu sesuai dengan nisbah dan presentase yang disepakati antara pihak nasabah dengan pihak BMT. Dengan adanya usaha kecil menengah diharapkan dapat membangun kembali perekonomian bangsa Indonesia dan membantu Negara ini untuk bangkit kembali dari krisis ekonomi yang berkepanjangan, shingga kemakmuran dan kesejahteraan rakyat dapat tercapai sesuai cita cita bangsa ini.

\section{KESIMPULAN}

Berdasarkan hasil penelitian dan pembahasan yang telah diuraikan pada bab sebelumnya, maka penulis dapat menarik beberapa kesimpulan sebagai berikut:

1) Latar belakang Koperasi BMT Fajar dalam memberikan pembiayaan mudhorobah kepada pengusaha kecil menengah disebabkan sesuai dengan misi dari BMT Fajar yaitu sebagai lemba keuangan mikro syariah yang membantu dan mendorong kemaslahatan usaha kecil menenengah dengan memberikan pembiayaan sesuai prinsip prinsip syariah yang bebas dari riba. Dengan adanya pembiayaan mudhorobah dari BMT Fajar, diharapkan dapat membantu permodalan bagi usaha kecil menengah di wilayah Kecamatan Cileungsi dan ikut berperan serta dalam pembangunan ekonomi bangsa Indonesia, sehingga terwujud kesejahteraan masyarkat Indonesia.

2) Adapun prosedur pembiayaan di koperasi jasa keuangan Syariah BMT Fajar, diantaranya: Sosialisai, Analisis, Jaminan, persetujuan pembiayaan, akad, pencairan pembiayaan, perhitungan bagi hasil, pembayaran angsuran dan monitoring. Dan pihak BMT akan memantau jalan usaha yang dilakukan oleh calon anggota serta memberikan solusi dan saran ketika ada permasalahan agar usaha berjalan lancar.

3) Peranan Koperasi Jasa Keuangan Syari'ah BMT Fajar terhadap perkembangan usaha kecil menengah di kecamatan CileungsiBerdasarkan hasil temuan yang diperoleh dari hasil lapangan, bahwa BMT Fajar sangat berperan dalam meningkatkan perkembangan usaha kecil menengah di kecamatan cileungsi. Hal ini dapat dilihat dari perkembangan usaha kecil menengah yang mengalami peningkatan dari tahun ketahun.

\section{DAFTAR PUSTAKA}

Abdullah Zaky Al-Kaaf, Ekonomi dalam Perspektif Islam, Bandung: CV Pustaka Setia, 2002.

Ahmad Ifham Sholihin, Pedoman Umum Lembaga Keuangan Syariah, Jakarta: Gramedia Pustaka Utama, 2010, hlm. 172.

Arikunto, Suharsimi, Prosedur Penelitian Suatu Praktek, Jakarta: Rineka Cipta, 1991.

Ascarya, Akad dan Produk Bank Syariah, Jakarta: PT. Raja Grafindo Persada, 2008.

Didik Ahmad Supadie, Sistem Keuangan Ekonomi Syariah Dalam Pemberdayaan Ekonomi Rakyat, Semarang; Pustaka Rizki Putra, hlm. 55-58.

Hartanto, Jogiyanto, Strategi Penelitian Bisnis, Yogyakarta: Andi, 2018.

Kamir, Bank dan Lembaga Keuangan lainnya, Jakarta: PT. Raja Grafindo Jakarta, 2005, hlm. 92.

M. Nadzaratuzzaman H, Hasan Ali, A Bahrul Muhtasib, Materi Dakwah Ekonomi Syariah, Jakarta: PKES, 2018, hlm. 168.

Moleong, Lexy J, Metode Penelitian Kualitatif \& RND, Bandung: Alfabeta, 2007.

M. Nur Al Arif, Dasar-dasar Pemasaran Bank Syariah, Bandung: Alvabeta, 2010, hlm. 4.

Muhammad, Lembaga-lembaga Keuangan Umat Kontemporer, Yogyakarta: UII Press, 2000, hlm. 119. 
Muhammad, Pengantar Akuntansi Syariah, Jakarta: Salemba Empat, 2002, hlm. 260.

Muhammad, Lembaga-lembaga Keuangan Umat Kontemporer, 2000, hlm.17-18.

Muhammad, Bank Syariah. Yogyakarta: Ekonisia, 2002.

Muhammad Ridwan, Manajemen Baitul Maal Wat Tamwil (BMT). Yogyakarta: UII Press, 2004.

M. Syafi'i Antonio, Bank Syariah Dari Teori ke Praktek, Jakarta: Gema Insani, 2001, hlm. 95.

Perwataatmadja, Karnaen A, Membumikan Ekonomi Islamdi Indonesia, Depok: Usaha Kami. 1996.

Pandia, Frianto, Manajemen dana dan Kesehatan Bank, Jakarta: Rineka Cipta, 2012.

Sudarsono, Heri, Bank dan Lembaga Keuangan Syariah, Yogyakarta: Ekonisia, 2003.

Soekanto, Soerjono, Pengantar Penelitian Hukum, Jakarta: Universitas Indonesia Press, 1986.

Sugiono, Metode Penelitian Kualitatif \& RND, Bandung: Alfabeta, 2010.

Sukmadinata, Nana Syaodih, Metode Penelitian Pendidikan. Bandung: Remaja Rosdakarya, 2007.

Sutan Remy Syahdeni, Perbankan Islam dan Kedudukannya dalam tata Hukum Perbankan Indonesia, Jakarta: Raja Grafindo Persada, 2002, hlm. 26.

Usman, Rachmadi, Aspek-aspek Hukum Perbanjan Islam di Indoesia, Bandung: PT. Citra Aditiya Bakti, 2002.

Zainul Arifin, Dasar-dasar Manajemen Bank Syariah, Jakarta: Pustaka Alfabeth, 2005, hlm. 210.

Zed Mestika, Metode Penelitian Kepustakaan, Jakarta: Yayasan Obor Indonesia, 2004.

\section{Skripsi}

Ananda, F., \& Setiawan, A. H. Analisis perkembangan Usaha mikro dan kecil setelah memperoleh pembiayaan mudhorobahdari BMT At-Taqwa
Halmahera di Kota Semarang (Doctoral dissertation, Universitas Diponegoro), 2011.

Dewi, E. K., \& Astari, A. Peran pembiayaan Mudhorobah dalam pengembangan kinerja usaha mikro pada BMT (Baitul maal watamwil).Law and justice, 2(2), 113-123, 2018.

Heny yuningrum, Mengukur Kerja Operasional BMT Pada Tahun 2010 ditinjau Dari Segi Efisiensi dengan Data Envelopment Analisis (DEA), Studi Kasus BMT di Semarang: 2012, hlm.39

Iswanto, M Alif. Pengaruh Pembiayaan Mudhorobah terhadap peningkatan pendapatan nasabah di BMT AL-Falah Sumber Kabupaten Cirebon. Skripsi Sarjana: Jurusan Muamalah Ekonomi Perbankan Islam. Cirebon: 2012.

Prasetya, R. A., \& Herianingrum, S peranan Baitul maal wat tanwil meningkatkan usha mikro melalui pembiayaan Mudhorobah. JURNAL SYARIKAH: JURNAL EKONOMI ISLAM, 2(2), 2016

Utomo, Budi. Analisis Pembiayaan Mudhorobah Pada Bank Syariah Mandiri Kantor Cabang Pembantu Banyumanik. Skripsi Sarjana: Jurusan Syariah dan ekonomi Islam. Salatiga: 2014.

\section{Internet}

http:/ / bmtfajar.blogspot.com/2015/09/pembiayaa n.html, BMT Fajar, 2015, (3 mei 2020 : 09.41)

https://qazwa.id/blog/mudharabah, Qazwa, 2018 (3 mei 2020: 09.28)

Silmikaffah, "Fungsi dan peranan Lembaga keuangan", wordpress.com.2013.http:/www.silmikaffah.w ordpress.com/?s=Fungsi+dan+peranan+lemba ga + keuangansubmit $=$ search .

https://www.djkn.kemenkeu.go.id/artikel/baca/ 13317/UMKM-Bangkit-Ekonomi-IndonesiaTerungkit.html (24 oktober 2020: 09.54)

https://www.medcom.id/ekonomi/analisaekonomi/5b2VgYvb-babak-baru-bmt-diindonesia (24 oktober 2020: 10.27) 